Proc. Estonian Acad. Sci. Biol. Ecol., 2004, 53, 2, 106-115

\title{
Total organic carbon load on the Gulf of Finland from its Russian catchment area
}

\author{
Sergey A. Kondratyev", Galina A. Alyabina, Igor V. Bovykin, and \\ Igor N. Sorokin
}

Institute of Limnology, Russian Academy of Sciences, Sevastyanova 9, St. Petersburg, 196105 Russia

Received 9 December 2002, in revised form 27 March 2004

\begin{abstract}
The studies based on the fieldwork of 1991-93 and 1996-98 show that the highest total organic carbon emission in the Russian area of the Gulf of Finland catchment originates from urban areas and forests. The total organic carbon washout from the northern areas of the catchment is about $10 \%$ higher than from the southern areas. This is due to differences in the annual runnoff and soil types. The results of the application of a mathematical model to an experimental catchment show that a doubling of the agricultural area would lead to a $19 \%$ decrease in the annual total organic carbon load. However, a $4 \%$ increase in the annual total organic carbon load would be expected in the second half of the 21 st century as a response to future climate change.
\end{abstract}

Key words: total organic carbon, non-point emission, washout, load.

\section{INTRODUCTION}

The transport of nutrients and pollutants is deeply interconnected with the transport of the total organic carbon (TOC) both in terrestrial and aquatic ecosystems. Also, TOC influences the intensity of biological processes in a water body. Thus evaluation of the TOC load on an aquatic system is indispensable for the study of the ecological state of a water body and its catchment area (Alyabina \& Sorokin, 1997).

The nutrient load on the Gulf of Finland (GoF) was studied in the framework of the Estonian-Finnish-Russian joint project "The Gulf of Finland Year 1996" (Pitkänen et al., 1997). It was shown that in the late 1980s-mid-1990s the Russian

*Corresponding author, kondratyev@limno.org.ru 
area of the GoF catchment drained about $60 \%$ nitrogen and $80 \%$ phosphorus of the total land-based loads on the GoF. The TOC load on the GoF has not been assessed previously.

The aim of the present study was to assess how different types of land cover and landscapes influence TOC non-point emission, washout of river catchment areas, and load on the Russian part of the GoF and its parts. For that purpose, fluxes $\left(\mathrm{kg} \mathrm{km}^{-2} \mathrm{yr}^{-1}\right)$ of TOC non-point emission in homogeneous catchments and TOC washout of different catchments, located in various landscapes, were estimated. As a result, the TOC load $\left(\mathrm{t} \mathrm{yr}^{-1}\right)$ on the GoF and different parts of its coastal zone was estimated. Additionally, the sensitivity of seasonal TOC loads to land use and climate change was assessed in the case of an experimental water body.

\section{DESCRIPTION OF THE STUDY AREA}

The area of the Russian part of the GoF catchment is $304000 \mathrm{~km}^{2}$. It includes the Lake Ladoga catchment $\left(276000 \mathrm{~km}^{2}\right)$, the Neva River immediate catchment $\left(5000 \mathrm{~km}^{2}\right)$, and the GoF immediate catchment $\left(23000 \mathrm{~km}^{2}\right)$. The Karelian Isthmus with a surface area of about $14000 \mathrm{~km}^{2}$ is located between the GoF and Lake Ladoga and forms part of the Lake Ladoga catchment. This area includes two kinds of landscapes: a ridge (Vyborg Selg) and a hilly plain (Isachenko et al., 1965). The Luga-Narva Lowland is named after two major rivers - the Narva and the Luga, which drain from areas in the south and southeast into the bays with the same names. An Ordovician plateau is located to the south of the clint and is characterized by wide-spread karst areas. The southern part of the GoF immediate catchment is covered by a lowland in front of the clint and LugaNarva lowland landscapes.

The proportion of forest-covered areas in the GoF catchment decreases in the direction from north to south from 70 to $37 \%$. Marshes and marshlands cover more than $30 \%$ of the area. On some lowland catchments upper marshes can cover more than $50 \%$ of the area. On average arable lands make up 10-20\%. The most cultivated part of the GoF catchment is the Ordovician plateau, where arable lands constitute up to $30 \%$ of the area.

In the studied region mainly podzolic, soddy-podzolic, hydromorphic, and marshy soils occur. More than $70 \%$ of the soils of the Karelian Isthmus contain parent rock of light granulometric composition. Also, there are ferrous humic illuvial podzols. In the southern zones of the cathment most soils are parent rock of rather heavy granulometric composition. On the Ordovician plateau there are soddy carbonate and humic gley soils.

The annual amount of precipitation varies from 552 to $727 \mathrm{~mm}$. About 2/3 $(66 \%)$ of this amount falls as rain, $19 \%$ as snow, and $15 \%$ is mixed precipitation. The snow cover period lasts $4-5$ months. The hydrographic net of the northern 
part of the GoF catchment area consists of the Seleznevka, Gorokhovka, and Chernaya rivers and other small watercourses. The main tributaries in the southern area are the Kovashi, Voronka, Sista, and Luga rivers (Fig. 1). The drainage density varies from 0.16 to $0.70 \mathrm{~km} \mathrm{~km}^{-2}$. In the karst areas this index falls to $0.07 \mathrm{~km} \mathrm{~km}^{-2}$. The annual runoff ranges from $10.0 \mathrm{~L} \mathrm{sec}^{-1} \mathrm{~km}^{-2}$ for the northern part to $7.0 \mathrm{~L} \mathrm{sec}^{-1} \mathrm{~km}^{-2}$ for the southern part of the GoF catchment.

Lake Krasnoe with its catchment (Fig. 1), which is located within the Lake Ladoga catchment $100 \mathrm{~km}$ north of St. Petersburg, was chosen as an experimental water body for testing and applications of a runoff and washout dynamic model. The water surface area of Lake Krasnoe is $9.2 \mathrm{~km}^{2}$; its catchment area is $160 \mathrm{~km}^{2}$. Of the catchment area $60 \%$ is forested; the rest consists of marshes, arable lands, and urban areas.

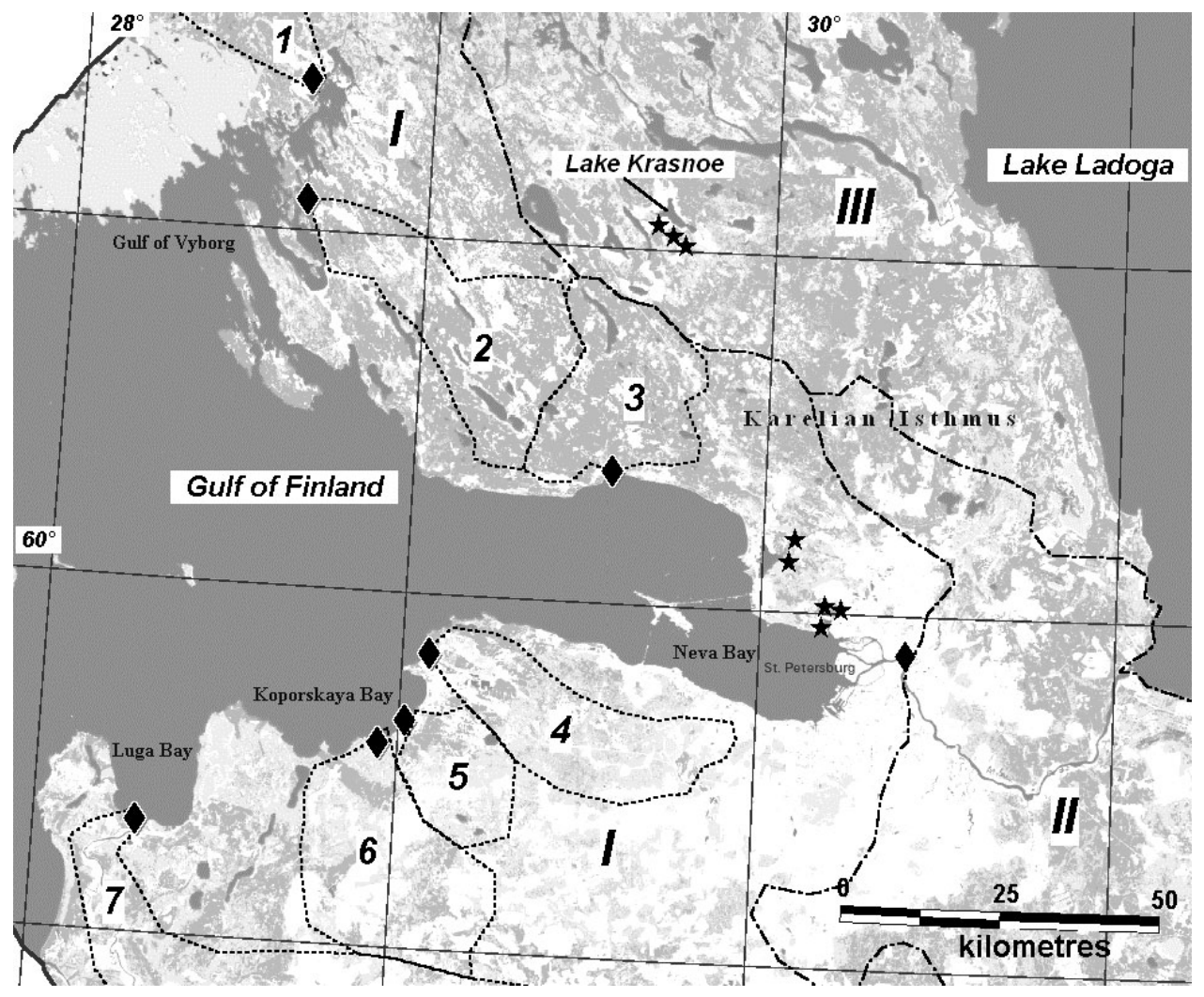

Fig. 1. Scheme of the Russian part of the GoF catchment and location of stations: GoF immediate catchment (I), Neva River immediate catchment (II), Lake Ladoga catchment (III); catchments of Seleznevka (1), Gorokhovka (2), Chernaya (3), Kovashi (4), Voronka (5), Sista (6), and Luga (7) rivers; stations of the hydrological and hydrochemical network $(\downarrow)$ and stations of the non-point emission study $(\star)$. 


\section{MATERIALS AND METHODS}

Field studies of TOC non-point emission in small catchments with homogeneous land cover (forests, marshes, arable lands, urban areas) of the GoF catchment were conducted in 1991-93 and 1996-98. The short length of watercourses (1-2 km) in small homogeneous catchments allowed us to neglect the transformation of substances in the channel. It was assumed that the TOC washout of such catchments adequately represents the emission in the studied landscape.

As the second step we studied the TOC washout of the main GoF tributaries in various landscapes and the TOC load on the GoF and its parts. A temporary hydrological and hydrochemical network was organized. It included 16 stations of different kinds of land cover and GoF tributaries. Water discharges and chemical samples were collected simultaneously at the gauge stations. The frequency of measurements was determined by the regime of runoff: every week during the spring flood, two times a month during the autumn flood, and once a month during the drought. Also, the standard State Hydrometeorological Service network data were used.

The concentration of TOC in water was calculated by $\mathrm{COD}_{\mathrm{cr}}$ values in native water samples. It means that TOC is a sum of dissolved and particulate organic carbon.

After each measurement fluxes of non-point TOC emission $K_{\mathrm{e}}$ in small homogeneous catchments and TOC washout $K_{\text {out }}$ of river catchments were calculated by means of the equation:

$$
K_{i}=\frac{C_{i} R_{i}}{A_{\mathrm{c}}}
$$

where $A_{\mathrm{c}}$ is the catchment area, $C_{i}$ and $R_{i}$ are respectively the concentration of TOC and runoff depth after $i$ th measurement. Finally, the mean values $K_{\mathrm{e}}^{\text {mean }}$ and $K_{\text {out }}^{\text {mean }}$ and the standard error $S_{\%}$ were assessed:

$$
K^{\text {mean }}=\frac{1}{n} \sum_{i=1}^{n} K_{i}, \quad S_{\%}=\frac{S_{K}}{K^{\text {mean }}} 100 \%, \quad S_{K}=\sqrt{\frac{\sum_{i=1}^{n} K_{i}^{2}}{(n-1)(n)}},
$$

where $n$ is the number of measurements.

TOC load $I$ and specific load $L$ per unit of aquatic area $A_{\mathrm{w}}$ were calculated by means of the equations:

$$
I=\sum_{j=1}^{m} K_{\mathrm{out}_{-} j}^{\text {mean }} A_{\mathrm{trc}_{-} j}+\sum_{k=1}^{l} K_{\mathrm{e}_{-} k}^{\text {mean }} A_{\mathrm{imc}_{-} k} \quad \text { and } \quad L=\frac{I}{A_{\mathrm{w}}},
$$

where $K_{\mathrm{out}_{-} j}^{\text {mean }}$ and $A_{\mathrm{trc}_{-} j}$ are the flux of TOC washout and the catchment area of the $j$ th tributary, respectively; $K_{\mathrm{e}_{-} k}^{\text {mean }}$ and $A_{\text {imc }_{-} k}$ denote respectively the flux 
of TOC emission and the catchment area for the $k$ th part of the immediate catchment, $m$ is the number of tributaries, $l$ is the number of the parts of the immediate catchment between the tributary catchments.

A dynamic mathematical model developed at the Institute of Limnology (Kondratyev, 2000; Kondratyev \& Bovykin, 2000; Kondratyev \& Moiseenkov, 2003) was used for the assessment of seasonal changes of runoff and TOC washout in the experimental catchment of Lake Krasnoe. The model includes the submodels of snow cover, snow melt, evapotranspiration, soil moisture, runoff (slow and fast), and phosphorus and organic carbon load on the aquatic system (Fig. 2).

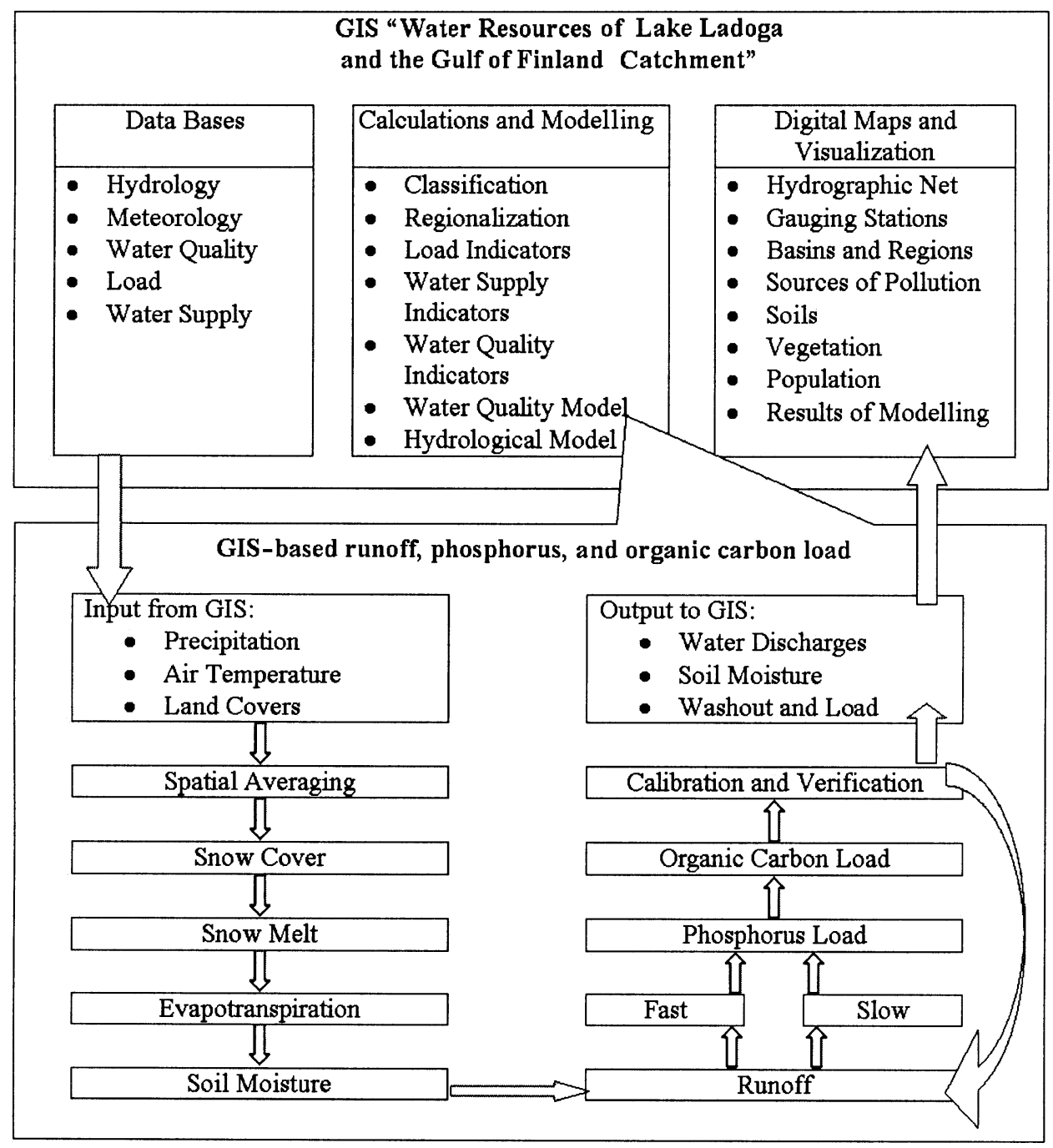

Fig. 2. Scheme of the GIS-based runoff, phosphorus, and organic carbon load model. 
The model is based on the Geographical Information System (GIS) "Water Resources of Lake Ladoga and the Gulf of Finland Catchment" (Kondratyev et al., 2000). The time step of the model is one month. The input climatic parameters of the model are air temperature and precipitation. Fluxes of non-point emission were used as parameters of the organic carbon load submodel.

\section{RESULTS AND DISCUSSION}

Calculated values of fluxes of TOC non-point emission $\left(\mathrm{kg} \mathrm{km}^{-2} \mathrm{yr}^{-1}\right)$ for various kinds of land cover for the Russian part of the GoF catchment area are presented in Table 1. The results of non-point emission assessment show the highest values of TOC emission fluxes for urban areas and forests. As for agricultural lands, their share in the fluxes of TOC emission is low.

The fluxes of TOC washout $\left(\mathrm{kg} \mathrm{km}^{-2} \mathrm{yr}^{-1}\right)$ were assessed for the main tributaries of the GoF (Seleznevka, Gorokhovka, Chernaya, Kovashi, Voronka, Sista, Luga, and Neva). The presented results (Table 2) allow a comparison of the fluxes of TOC washout for the landscapes of northern and southern tributaries of the GoF. The fluxes for the northern landscapes (Vyborg Selg and hilly plain) are about $10 \%$ higher than for the southern lowlands. The reason for this is differences in annual runoff and soil types. The Karelian Isthmus is located in a geochemical province with an intensive transport of iron, manganese, and organic carbon whereas in the southern part of the immediate GoF catchment the transport of organic carbon is limited by soddy carbonate soil. The flux of TOC washout of the Neva River depends on the TOC content in Lake Ladoga and the influence of St. Petersburg.

Using equations (3) the assessment of the TOC load $\left(\mathrm{t} \mathrm{yr}^{-1}\right)$ into the GoF and its bays (Gulf of Vyborg, Koporskaya, Luga, and Neva bays, Fig. 1) was carried out (Table 3). The value of the flux of the TOC washout for the Seleznevka catchment $K_{\text {out }}^{\text {mean }}$ was defined as the flux of the TOC washout of the Vyborg Selg

Table 1. Fluxes of non-point TOC emission $\left(K_{\mathrm{e}}^{\text {mean }}, \mathrm{kg} \mathrm{km}^{-2} \mathrm{yr}^{-1}\right)$ for various kinds of land cover in the GoF catchment area. Number of measurements 66

\begin{tabular}{l|r}
\hline \multicolumn{1}{c|}{ Land cover } & \multicolumn{1}{c}{$K_{\mathrm{e}}^{\text {mean }} / S_{\%}$} \\
\hline Marshes & $750 / 13.6$ \\
Forest & $1650 / 12.5$ \\
Arable lands & $300 / 13.0$ \\
Urban areas & $6900 / 13.3$
\end{tabular}


Table 2. Fluxes of TOC washout $\left(K_{\text {out }}^{\text {mean }}, \mathrm{kg} \mathrm{km}^{-2} \mathrm{yr}^{-1}\right)$ for the main tributaries of the GoF

\begin{tabular}{|c|c|c|c|c|}
\hline Tributary & $\begin{array}{l}\text { Catchment } \\
\text { area, } \mathrm{km}^{2}\end{array}$ & $\begin{array}{c}\text { Number of } \\
\text { measurements }\end{array}$ & $K_{\text {out }}^{\text {mean }} / S_{\%}$ & $\begin{array}{c}\text { Landscapes } \\
\text { (Isachenko et al., 1965) }\end{array}$ \\
\hline Seleznevka & 623 & 22 & $2100 / 22.1$ & Vyborg Selg \\
\hline Gorokhovka & 700 & 22 & $2700 / 25.1$ & Hilly plain \\
\hline Chernaya & 668 & 22 & $2200 / 24.2$ & Hilly plain \\
\hline Kovashi & 612 & 22 & $2100 / 24.8$ & Lowland in front of the clint \\
\hline Voronka & 286 & 22 & $1900 / 22.4$ & Lowland in front of the clint \\
\hline Sista & 672 & 22 & $1900 / 23.1$ & Lowland in front of the clint \\
\hline Luga & 12800 & 92 & 2000/11.2 & Narva-Luga Lowland \\
\hline Neva & 281000 & 92 & $2100 / 10.4$ & Combined \\
\hline
\end{tabular}

Table 3. TOC load and specific load per unit area of the GoF and its parts

\begin{tabular}{l|c|c|c|c}
\hline \multicolumn{1}{c|}{ Part of GoF } & $\begin{array}{c}\text { Surface area, } \\
\mathrm{km}^{2}\end{array}$ & $\begin{array}{c}\text { Catchment area, } \\
\mathrm{km}^{2}\end{array}$ & $\begin{array}{c}\text { TOC load, } \\
\mathrm{t} \mathrm{yr}^{-1}\end{array}$ & $\begin{array}{c}\text { TOC specific load, } \\
\mathrm{g} \mathrm{m}^{-2} \mathrm{yr}^{-1}\end{array}$ \\
\hline Gulf of Finland & 6126 & 304000 & 646884 & 105.6 \\
Gulf of Vyborg & 450 & 3434 & 8354 & 18.6 \\
Koporskaya Bay & 239 & 1929 & 3776 & 15.8 \\
Luga Bay & 212 & 13534 & 26845 & 126.6 \\
Neva Bay & 330 & 281550 & 602604 & 1826.0
\end{tabular}

landscape; the value of the flux of the TOC washout for the Gorokhovka and Chernaya catchments was defined as the flux of the TOC washout of the hilly plain landscape; the value of the flux of the TOC washout for the Kovashi, Voronka, and Sista catchments was defined as the flux of the TOC washout of the lowland in front of the clint landscape; the value of the flux of the TOC washout for the Luga catchment was defined as the flux of the TOC washout of the Narva-Luga lowland landscape. Also, the TOC specific load $\left(\mathrm{g} \mathrm{m}^{-2} \mathrm{yr}^{-1}\right)$ for the mentioned water areas was calculated.

Using the mathematical model mentioned above the influence of land use on the seasonal TOC load ( $\mathrm{t}$ month $\left.{ }^{-1}\right)$ into Lake Krasnoe was assessed. The model was tested for the series obtained from 1964 to 1984. The results of calculations of long-term TOC load into Lake Krasnoe during the hydrological year (NovemberOctober) show that a doubling of the agricultural area would lead to a $19 \%$ decrease in the annual TOC load. The most significant changes take place in April and May, during the spring floods (Fig. 3) because in that period the share of the fast component of runoff is the most substantial.

Comparison of expected changes of the TOC load on Lake Krasnoe under possible climate changes was carried out. Scenarios of air temperature and precipitation for the next 100 years constructed by means of the model of global 


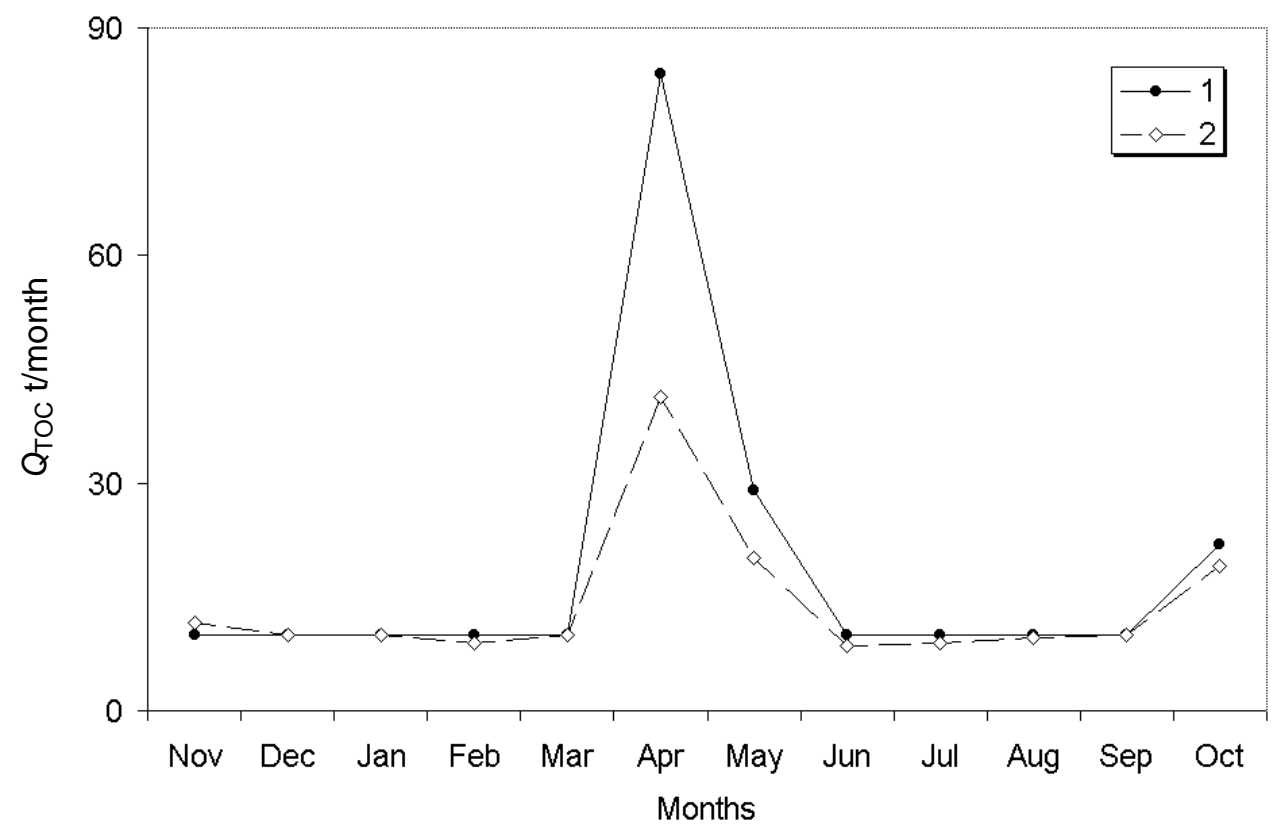

Fig. 3. Long-term TOC load on Lake Krasnoe (1) and the result of simulation for the doubled field area (2).

circulation ECHAM4/OPYC (Golytsyn et al., 2003) were used as input data in the mathematical model presented above. The results of calculation show that the future increase in precipitation and runoff and TOC specific load on the lake considered is not significant (Table 4). Probably, a $4 \%$ increase in the annual TOC load (compared with the annual TOC of the testing period) could be expected in the second half of the 21 st century. Thus, land use and climate changes influence the TOC load in the opposite directions but the influence of land use is more significant.

Table 4. Climatic parameters, runoff, and TOC specific load on Lake Krasnoe (period of model testing and forecast)

\begin{tabular}{|c|c|c|c|c|}
\hline \multirow[t]{2}{*}{ Period } & \multicolumn{4}{|c|}{ Average change over period } \\
\hline & $\begin{array}{l}\text { Air temperature, } \\
{ }^{\circ} \mathrm{C}\end{array}$ & $\begin{array}{l}\text { Precipitation, } \\
\mathrm{mm} \mathrm{yr}^{-1}\end{array}$ & $\begin{array}{l}\text { Runoff, } \\
\mathrm{mm} \mathrm{yr}^{-1}\end{array}$ & $\begin{array}{c}\text { TOC specific load, } \\
\mathrm{g} \mathrm{m}^{-2} \mathrm{yr}^{-1}\end{array}$ \\
\hline 1964-84 (period of testing) & 3.7 & 741 & 287 & 26.8 \\
\hline $2000-49$ & 5.6 & 693 & 285 & 26.2 \\
\hline 2050-99 & 7.1 & 744 & 301 & 28.0 \\
\hline
\end{tabular}




\section{CONCLUSIONS}

The field studies conducted in the Gulf of Finland catchment as well as the data analysis of a TOC series showed the highest TOC emission to originate from urban areas and forests. The TOC washout for the northern landscapes (Vyborg Selg and a hilly plain of the Karelian Isthmus) is about $10 \%$ higher than for the southern landscapes (lowland in front of the clint and the Narva-Luga Lowland). The reason for this difference in the values of TOC washout is differences in the annual runoff and soil types. The results of the application of a mathematical model to the Lake Krasnoe catchment showed that a doubling of the agricultural area would lead to a 19\% decrease in the annual TOC load compared with the annual load of the testing period. The most significant change would take place in April and May, during the spring flood. However, a $4 \%$ increase in the annual TOC load would be expected in the second half of the 21 st century as a response to the future climate changes. Thus, changes in the land use would affect the TOC load more significantly than climate changes.

\section{REFERENCES}

Alyabina, G. A. \& Sorokin, I. N. 1997. Phosphorus and organic matter transport in "CatchmentLake" System. Ekol. Khim., 6(3), 165-171 (in Russian).

Isachenko, A. G., Dashkevich, Z. V. \& Karnaukhova, E. V. 1965. Physical and Geographical Regions of Northwest of the USSR. Izdatel'stvo Leningradskogo Universiteta (in Russian).

Golytsyn, G. S., Efimova, L. K., Mokhov, I. I., Semenov, V. A. \& Khon, V. C. 2003. Changes of temperature of air and precipitation for the Lake Ladoga catchment according to results of long-term integration of ECHAM4/OPYC and HadCM3 models. Publ. Karelian Inst., Univ. Joensuu, Finland, 138, 449-455.

Kondratyev, S. A. 2000. Catchment modelling system (ILCM). Working Papers Karelian Inst., Univ. Joensuu, Finland, 2, 40-45.

Kondratyev, S. A. \& Bovykin, I. V. 2000. Hydrologic response of small lake and its drainage catchment to precipitation and air temperature changes. Publ. Karelian Inst., Univ. Joensuu, Finland, 129, 423-427.

Kondratyev, S. A. \& Moiseenkov, A. I. 2003. GIS-based model of water regime of Lake Ladoga drainage basin. Publ. Karelian Inst., Univ. Joensuu, Finland, 138, 62-67.

Kondratyev, S. A, Gronskaya, T. P., Druzhinin, V. S., Sikan, A. S., Efremova, L. V., Gayenko, V. I. \& Markova, E. G. 2000. Geographical information system "Water Resources of Lake Ladoga and the Gulf of Finland Catchment". Tr. Russk. Geogr. O-va, 132(4), 53-61 (in Russian).

Pitkänen, H., Kondratyev, S., Lääne, A., Gran, V., Kauppila, P., Loigu, E., Markovets, I., Pachel, K. \& Rumyantsev, V. 1997. Summary report of the working group loading. In Proceeding of Final Seminar of the Gulf of Finland Year 1996, Helsinki, Finland, pp. 9-18. 


\title{
Orgaanilise süsiniku koguvoog Soome lahte selle valgala Venemaa-osast
}

\author{
Sergei A. Kondratjev, Galina A. Aljabina, \\ Igor V. Bovõkin ja Igor N. Sorokin
}

Soome lahe Venemaal paiknevas valgalaosas pärineb suurim lahte suubuv orgaanilise süsiniku voog linnadest ja metsaaladelt. Piirkonna põhjaosast pärinev orgaanilise süsiniku voog ületab lõunaosast pärinevat $10 \%$. Matemaatilise mudeli rakendamine eksperimentaalsele valgalale näitas, et põllumajandusmaade pindala kahekordistamine vähendab orgaanilise süsiniku voogu $19 \%$.

21. sajandi teiseks pooleks prognoositava kliimamuutuse tagajärjel võib orgaanilise süsiniku voog kasvada $4 \%$. 